\title{
Informatics teaching in undergraduate nursing programs at Brazilian public institutions
}

\author{
Luiz Miguel Picelli Sanches ${ }^{1}$ \\ Rodrigo Jensen ${ }^{2}$ \\ Maria Inês Monteiro ${ }^{3}$ \\ Maria Helena Baena de Moraes Lopes ${ }^{4}$
}

This descriptive study aimed to verify the inclusion of subjects about informatics in undergraduate nursing programs at Brazilian (state and federal) public education institutions. The programs were located through the e-MEC system. The Internet was used to search for the curricula of the campuses offering the nursing program and identify subjects related to informatics. Eighty-one higher education institutions and 123 campuses were located. Only 100 campuses provided the curriculum on the Internet, 35 of which offered the subject. The highest proportion occurred in the Northeast $(46.1 \%)$ and the lowest in the North $(8.6 \%)$. The subject is mostly offered as an elective discipline $(57 \%)$ in the first and second year $(80 \%)$, with an average workload of 47 classroom hours. The low supply of this undergraduate subject goes against job market trends and the National Curriculum Guidelines for Undergraduate Nursing Programs.

Descriptors: Nursing Informatics; Higher Education; Curriculum.

\footnotetext{
${ }^{1}$ RN, Doctoral Student in Nursing, Departamento de Enfermagem, Faculdade de Ciências Médicas, Universidade Estadual de Campinas, SP, Brazil. Assistant Professor, Centro Acadêmico de Vitória, Universidade Federal de Pernambuco, PE, Brazil. E-mail: luiz.sanches@nutes.ufpe.br.

${ }^{2}$ RN, Doctoral Student in Nursing, Departamento de Enfermagem, Faculdade de Ciências Médicas, Universidade Estadual de Campinas, SP, Brazil. E-mail: rodrigojensen@yahoo.com.br.

${ }^{3}$ RN, Ph.D. in Nursing, Associate Professor, Departamento de Enfermagem, Faculdade de Ciências Médicas, Universidade Estadual de Campinas, SP, Brazil. E-mail: inesmon@fcm.unicamp.br.

${ }^{4}$ RN, Ph.D. in Genetics and Molecular Biology, Associate Professor, Departamento de Enfermagem, Faculdade de Ciências Médicas, Universidade Estadual de Campinas, SP, Brazil. E-mail: mhbaenaml@yahoo.com.br.
}

Corresponding Author:

Luiz Miguel Picelli Sanches

Universidade Federal de Pernambuco. Centro Acadêmico de Vitória

Núcleo de Enfermagem

Rua Alto do Reservatório, s/n

Bairro: Bela Vista

CEP: 55608-680, Vitória de Santo Antão, PE, Brasil

E-mail: luiz.sanches@nutes.ufpe.br 


\section{Ensino da informática na graduação em Enfermagem de instituições públicas brasileiras}

Este estudo descritivo objetivou verificar a inserção de disciplinas relacionadas à informática nos cursos de graduação em Enfermagem, de instituições de ensino superior federais e estaduais brasileiras. Os cursos de graduação foram localizados pelo sistema e-MEC. A busca da grade curricular dos campi que ofereciam o curso de Enfermagem foi realizada pela internet, identificando-se disciplinas relacionadas à informática. Foram localizadas 81 instituições de ensino superior e 123 campi. Apenas 100 campi disponibilizavam a grade curricular na internet e, desses, 35 campi ofereciam a disciplina. A maior proporção ocorreu na Região Nordeste $(46,1 \%)$ e, a menor, na Região Norte $(8,6 \%)$. A disciplina é oferecida em maior frequência como eletiva (57\%), no primeiro e segundo ano do curso ( $80 \%$ ) e com carga horária média de 47 horas-aula. A baixa oferta da disciplina na graduação contraria as tendências do mercado de trabalho e das Diretrizes Curriculares Nacionais do curso de graduação em Enfermagem.

Descritores: Informática em Enfermagem; Educação Superior; Currículo.

\section{Enseñanza de informática en la graduación en enfermería de instituciones públicas brasileñas}

Este estudio descriptivo objetivó verificar la inclusión de disciplinas relacionadas a la informática en los cursos de graduación en enfermería de instituciones de enseñanza superior federales y estatales brasileñas. Los cursos de graduación fueron localizados por el sistema e-MEC. La búsqueda del plan de estudios de los campus que ofrecían el curso de enfermería fue realizada por la internet, identificando disciplinas relacionadas a la informática. Fueron localizadas 81 instituciones de enseñanza superior y 123 campus. Apenas 100 campus disponen el plan de estudios en la internet $y$, de estos, 35 campus ofrecían la disciplina. La mayor proporción ocurrió en la región noreste $(46,1 \%)$ y, la menor, en la región norte $(8,6 \%)$. La disciplina es ofrecida con mayor frecuencia como electiva ( $57 \%)$, en el primero y segundo año del curso $(80 \%)$, con carga horaria promedio de 47 horas-clase. La baja oferta de la disciplina en la graduación contraría las tendencias del mercado de trabajo y de las Directrices Curriculares Nacionales del Curso de Graduación en Enfermería.

Descriptores: Informática Aplicada a la Enfermería; Educación Superior; Curriculum.

\section{Introduction}

Around the world, the growth in health information technology has generated the need to create professional education courses for the development, implementation and assessment of health systems. For the last two decades, professional education programs specialized in biomedical or health informatics have been encouraged.

Informatics teaching has been integrated in undergraduate health programs, providing minimum knowledge for these professionals, as users, to know about information and communication technology resources, with a view to the efficient and responsible use of information, knowledge processing methods and information and communication technologies ${ }^{(1)}$.

For more than a decade, scientific indications have identified the digital revolution in nursing, associating high-quality practices with computer use and the incorporation of new technologies ${ }^{(2)}$. This practice is also 
observed in education, demanding a better preparation to enable these professionals to adapt themselves and use the full range of information and communication technology(3).

The curriculum contents and definition of informatics competences in nursing has been discussed in scientific literature. Although the importance of these competences has been recognized globally, they have not been widely incorporated into undergraduate or graduate nursing curricula in different countries ${ }^{(4)}$.

In a research performed in the United States (USA), in which undergraduate nursing program coordinators served as subjects, it was identified that $80 \%$ of them considered that nursing graduates should possess nursing competences, such as knowledge about e-mail, word processing, bibliographic and internet searches, but only $33 \%$ reported that these competences were taught in the courses they coordinated(5). In Brazilian studies, this information is complemented, appointing that faculty and students' knowledge on informatics resources remains deficient, impeding them from using information and communication technologies in the different dimensions of nursing relations, in teaching, research, management and care delivery ${ }^{(3,6)}$.

Due to the lack of technological knowledge, some faculty display fear, insecurity and prejudice with regard to informatics. They feel excluded from the technological life world, and are unable to perceive the new routes students are experiencing with regard to technologies $^{(7)}$.

A research involving nursing students from a public college in Brazil showed that $94 \%$ has a computer with Internet access at home. The most frequent computer uses among the students were related to typing programs (94.4\%), Internet (91.3\%), research presentation $(88.8 \%)$ and bibliographic research $(86.1 \%)$. Part of the students demonstrated e-mail (44.4\%) and site navigation skills (47.2\%). The authors of that study defend that informatics subjects should focus not only on basic informatics training, but also allow students to glimpse potentials and limitations technological resources entail in professional practice ${ }^{(8)}$.

In the USA, nursing informatics certification has been accomplished for more than a decade(1). The first significant impact of publications on computer use in nursing teaching, focusing on informatics in the undergraduate and graduate curriculum, occurred in the 1980's, mainly in the USA. In Brazil, the first initiative towards computer use in education also dates back to the 1980 's ${ }^{(9)}$.
National Curriculum Guidelines for Undergraduate Nursing Programs, Art. $4^{\circ}$ - III rule that, as a part of nursing education, students should have access to the communication and information technology domain. Art. 50 - XV of the same resolution affirms that one of the objectives of nursing education is to provide students with the knowledge required to practice competences and skills for the adequate use of new information and communication technologies ${ }^{(10)}$.

Discussions are ongoing in Brazil, at federal level, about the implantation of computer systems for health information management. Public entities have manifested their position in favor of the implantation and integration of these systems for use at different healthcare levels, with a view to facilitating information access. This lead to the proposal of the Unified Health System (SUS) National Information and Health Informatics Policy (PNIIS), which aims to conduct "the computerization process of health work, in individual care as well as in collective health actions, with a view to obtaining the efficiency and quality gains technology permits, automatically generating the electronic records national information systems will be based on, thus resulting in more reliable information for management, knowledge production and social control"(11).

This policy presupposed the need to apply informatics in undergraduate teaching as well as in permanent education programs, strengthening and approximating learning skills and enhancing individual, social and professional development ${ }^{(12)}$.

In view of the determinations in the Curriculum Guidelines and the computerization trend of health services, questions arise about nursing education in Brazil. In their academic program, are nurses prepared for compliance with the informatics knowledge requisites the job market demands?

This study aimed to verify the inclusion of informatics related subjects in undergraduate nursing programs at Brazilian federal and state higher education institutions.

\section{Methods}

Data for this descriptive study were collected in November 2010.

Initially, undergraduate nursing programs at Brazilian federal and state higher education institutions were surveyed using the e-MEC(13) system, a resource offered by the Ministry of Education. Next, through the Internet, the curricula of the identified nursing programs were sought. 
All federal and state public higher education institutions that offered undergraduate nursing programs and whose curriculum was available for online consultation were included in the study. Thus, the course curricula were analyzed and informatics-related subjects were identified through the subject name and summary.

As no general rule exists to name the subjects or develop the program contents, the researchers considered that any form of offering informatics contents would comply with the study inclusion criteria. Thus, Health Informatics subjects were considered as any subjects whose summary referred to basic informatics teaching, whether applied or not, health information systems or informatics applied to health.

Absolute and relative frequencies were calculated for the study variables and data were presented in tables and a graph.

\section{Results}

In November 2010, 1109 undergraduate nursing programs were offered in Brazil, distributed between public and private higher education institutions. Table 1 presents the distribution of federal and state public higher education institutions offering undergraduate nursing programs and of their campuses ${ }^{(13)}$.

Table 1 - Distribution of undergraduate nursing programs at federal and state public higher education institutions - Brazil, 2010

\begin{tabular}{lcccccc}
\hline & \multicolumn{2}{c}{ Institutions } & & \multicolumn{2}{c}{$\begin{array}{c}\text { Campuses/ } \\
\text { Courses }\end{array}$} \\
\cline { 2 - 3 } \cline { 6 - 7 } & $\mathbf{n}$ & $\%$ & & $\mathbf{n}$ & $\%$ \\
\hline Federal higher education institutions & 46 & 56.8 & & 65 & 52.8 \\
State higher education institutions & 35 & 43.2 & & 58 & 47.2 \\
Total & 81 & 100 & & 123 & 100 \\
\hline
\end{tabular}

Source: Ministry of Education, 2010
In Table 2, the distribution of informatics-related subjects is displayed according to the federal and state public higher education institutions that offer their curricula online $(n=100)$. It was observed that $35(35 \%)$ of these nursing programs offered informatics-related subjects.

In the group of undergraduate nursing programs offered at public state and federal higher education institutions (123), nine (13.8\%) federal and 14 (24.1\%) state higher education institution campuses did not make their curricula available online.

Table 2 - Distribution of informatics-related subjects according to federal and state public higher education institutions that offer their curricula on the Internet Brazil, 2010

\begin{tabular}{|c|c|c|c|c|}
\hline & \multicolumn{2}{|c|}{$\begin{array}{c}\text { Federal Campuses/ } \\
\text { Courses }\end{array}$} & \multicolumn{2}{|c|}{$\begin{array}{c}\text { State Campuses/ } \\
\text { Courses }\end{array}$} \\
\hline & $\mathbf{n}$ & $\%$ & $\mathrm{n}$ & $\%$ \\
\hline $\begin{array}{l}\text { Presence of informatics- } \\
\text { related subjects }\end{array}$ & 23 & 41.1 & 12 & 27.3 \\
\hline $\begin{array}{l}\text { Absence of informatics- } \\
\text { related subjects }\end{array}$ & 33 & 58.9 & 32 & 72.7 \\
\hline Total & 56 & 100 & 44 & 100 \\
\hline
\end{tabular}

The geographical distribution of undergraduate nursing programs at Brazilian public federal and state institutions, in comparison with the supply of informatics subjects in the curricula, is displayed in Figure 1.

The highest proportion of informatics-related subjects was offered in the Northeast (46.1\%) and Southeast $(45.8 \%)$, considering the number of campuses in each region. Proportionally to the number of campuses, the smallest number $(8.6 \%)$ of programs offering informatics-related subjects is located in the North of Brazil.

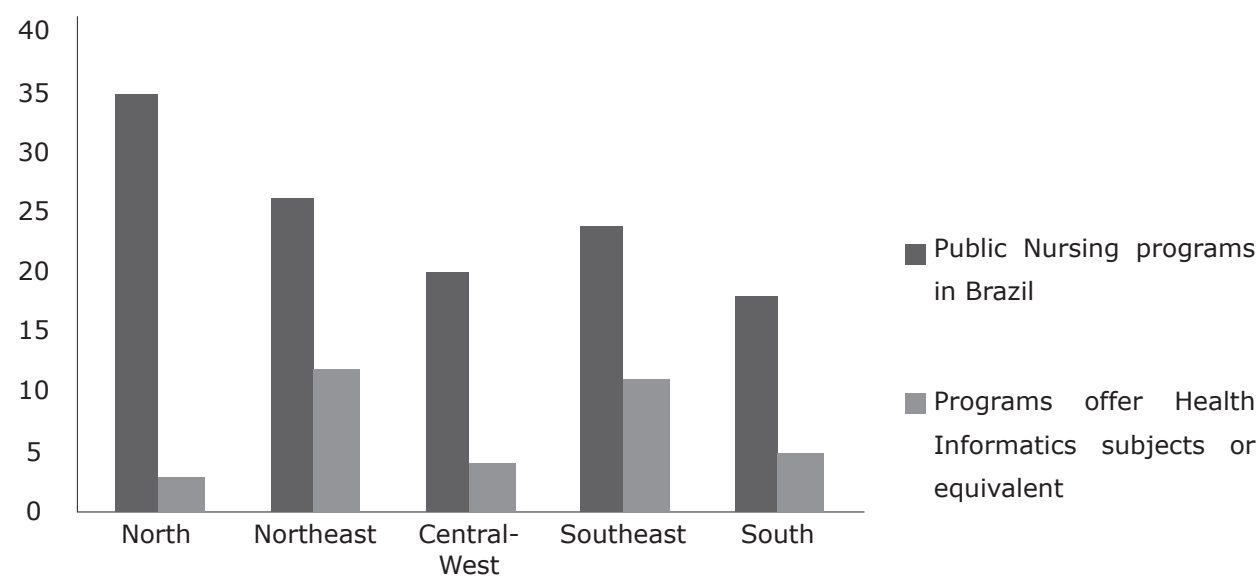

Figure 1 - Geographical distribution of undergraduate nursing programs at public federal and state higher education institutions and supply of informatics-related subjects - Brazil, 2010 
Among the 35 nursing course curricula under analysis that offer some informatics-related subject, on $15(43 \%)$ campuses the subject is offered as a compulsory part of the curriculum and, on 20 (57\%) campuses, as an elective subject. Five undergraduate nursing programs at the colleges analyzed offer two or more informatics-related subjects.

On only 20 campuses, the semester was informed when the informatics subject is offered, 16 (80\%) of which were offered between the first and second undergraduate program year. The mean hour load was 47 class hours.

\section{Discussion}

In this study, it could be identified that most undergraduate nursing programs in Brazil offered at federal and state higher education institutions do not offer informatics-related subjects as part of the curriculum. This finding may be underestimated, as some institutions' curriculum could not be located on the Internet.

Based on the National Curriculum Guidelines for Undergraduate Nursing Programs and in view of current job market requirements, such as the trend to set up information systems in health services, this data is a source of concern and evidences that, possibly, nurses are not being prepared to work at institutions that need trained professionals to interact with information technologies.

At federal higher education institutions, a higher frequency of informatics subjects (41.1\%) was found than at state institutions (27.3\%). Despite this difference, neither state nor federal institutions comply with the professional training demands resulting from the SUS National Information and Health Informatics Policy(11).

The choice of the best timing to offer an informatics subject, with a view to discussing its application in health practice, remains controversial and literature offers little evidence. In this study, it was identified that $80 \%$ of the programs offered the subject in the first or second program year, showing that informatics subjects have predominantly been offered at the start of the undergraduate program, when students do not have practical experience yet at health institutions.

The subject informatics applied to health should be adapted to students' advances and used to stimulate learning in nursing education. To give an example, teaching on patient files should be introduced after the student has gained some clinical experience, but not at the end of the program, so that students can benefit from this knowledge in their final clinical training practicums $^{(1)}$.

Technology and online teaching strategies can be used positively in nursing education. Using nursing teaching technologies and teaching students to use technologies and informatics can enhance students learning with regard to psychomotor skills associated with software and hardware use, which will offer benefits in a care environment where technology is used. Students' exposure to technology and informatics in nursing teaching can strongly influence health care ${ }^{(14)}$.

The Northeast and Southeast proportionally revealed a larger number of institutions offering informatics subjects in undergraduate nursing education. These factors may be associated with the fact that these regions are technological hubs, in which professionals may have greater access to computer technologies. The South of Brazil, where the first Brazilian initiative to use informatics in nursing education was published ${ }^{(9)}$, was not responsible for the highest percentages.

One possible limitation is that some program could introduce informatics-related contents into non-specific subjects, which could not be identified in this study, as the programs did not offer the subject contents. Some subjects in which informatics-related contents could be presented are nursing diagnosis, the nursing process or even practicum areas that permit students' contact with hospital information and electric patient file systems; as well as informatics resources used in the teachinglearning process ${ }^{(15)}$. Although this can be the case in some courses, specific subjects to discuss informatics applied to health allow students to get to know a wider range of applications and resources.

The researchers faced great difficulty to locate the undergraduate nursing program curricula on the Internet. Some situations that hampered the search were outdated sites, deficient website structure and difficult information access. Such factors make it difficult for students, teachers and researchers to get information about the programs. In addition, as these are public institutions, they should offer information to the society that maintains them.

Entities like the International Medical Informatics Association offer recommendations for health informatics teaching ${ }^{(1)}$. In Brazil, however, the lack of trained nurses in this knowledge area and the nondefinition of minimum contents to be addressed in students' education can contribute to the low supply of this subject at higher education institutions. 
Research is due on the causes for the low supply of informatics subjects in nursing curricula and to propose minimum program contents for health informatics subjects.

\section{Conclusion}

In this study, it was identified that, in Brazil, only 35 undergraduate nursing programs at federal and state higher education institutions offered informatics-related subjects in their curriculum, available on the Internet, in 2010. This situation does not follow current nursing job market trends and does not comply with National Curriculum Guidelines for Undergraduate Nursing Programs.

It is questioned who is responsible for providing health informatics education to nurses? How will the profession stay in tune with innovations and propose technological developments if it is not being prepared for this?

\section{References}

1. Mantas J, Ammenwerth E, Demiris G, Hasman A, Haux $\mathrm{R}$, Hersh $\mathrm{W}$, et al. Recommendations of the International Medical Informatics Association (IMIA) on education in biomedical and health informatics. Methods Inf Med. 2010;49:1-16.

2. Mendes IAC, Trevizan MA, Évora YDM. Comunicação e enfermagem: tendências e desafios para o próximo milênio. Esc Anna Nery. 2000;4(2):217-24.

3. Silva ISA, Marques IR. Conhecimento e barreiras na utilização dos recursos da Tecnologia da Informação e Comunicação por docentes de enfermagem. J Health Inform. 2011;3(1):3-8.

4. Marin HF. Nursing informatics: current issues around the world. Int J Med Inform. 2005;74:857-60.

5. McNeil BJ, Elfrink VL, Bickford CJ, Pierce ST, Beyea $\mathrm{SC}$, Averill C, et al. Nursing information technology knowledge, skills, and preparation of student nurses, nursing faculty, and clinicians: a U.S. Survey. J Nurs Educ. 2003;42(8):341-9.

6. Cogo ALP, Silveira DT, Pedro ENR, Tanaka RY, Catalan VM. Aprendizagem de sinais vitais utilizando objetos educacionais digitais: opinião de estudantes de enfermagem. Rev Gaúcha Enferm. $2010 ; 31(3): 435-41$.

7. Peres HHC, Kurcgant P. O ser docente de enfermagem frente ao mundo da informática. Rev. Latino-Am. Enfermagem. 2004;12(1):101-8.
8. Peres HHC, Meira KC, Leite MMJ. Ensino de didática em enfermagem mediado pelo computador: avaliação discente. Rev Esc Enferm USP. 2007;41(2):271-8.

9. Évora YDM, Fávero N, Trevizan MA, Melo MRAC. Evolução histórica da aplicação do computador na enfermagem (1965-1998). Acta Paul Enferm. 2000;13(E):143-7.

10. Conselho Nacional de Educação (BR). Câmara de Educação Superior. Resolução CNE/CES 3/2001. Diretrizes Curriculares Nacionais do Curso de Graduação em Enfermagem. Diário Oficial da União. Brasília, 09 nov. 2001. Seção 1, p. 37. Brasília; 2006. [acesso 28 nov 2010]. Disponível em: http://portal.mec.gov.br/ cne/arquivos/pdf/CES03.pdf

11. Minitério da Saúde (BR). DATA SUS - Departamento de Informática do SUS. Políticas. [acesso 26 jan 2011]. Disponível em: http://www2.datasus.gov.br/DATASUS/ index.php?area $=05$

12. Trevizan MA, Mendes IAC, Mazzo A, Ventura CAA. Investimento em ativos humanos da enfermagem: educação e mentes do futuro. Rev. Latino-Am. Enfermagem. [periódico na Internet]. 2010; [acesso 13 dez 2010]. 18(3). Disponível em: http://www.scielo.br/ pdf/rlae/v18n3/pt_24.pdf

13. Ministério da Educação (BR). e-MEC. [acesso 26 nov 2010]. Disponível em: http://emec.mec.gov.br/

14. Ainsley B, Brown A. The impact of informatics on nursing education: a review of the literature. J Contin Educ Nurs. 2009;40(5):228-32.

15. Barbosa SFF, Marin HF. Web-based simulation: a tool for teaching critical care nursing. Rev. Latino-Am. Enfermagem. 2009;17(1):7-13.
Received: Jan. $31^{\text {st }} 2011$ Accepted: Sept. 20th 2011 